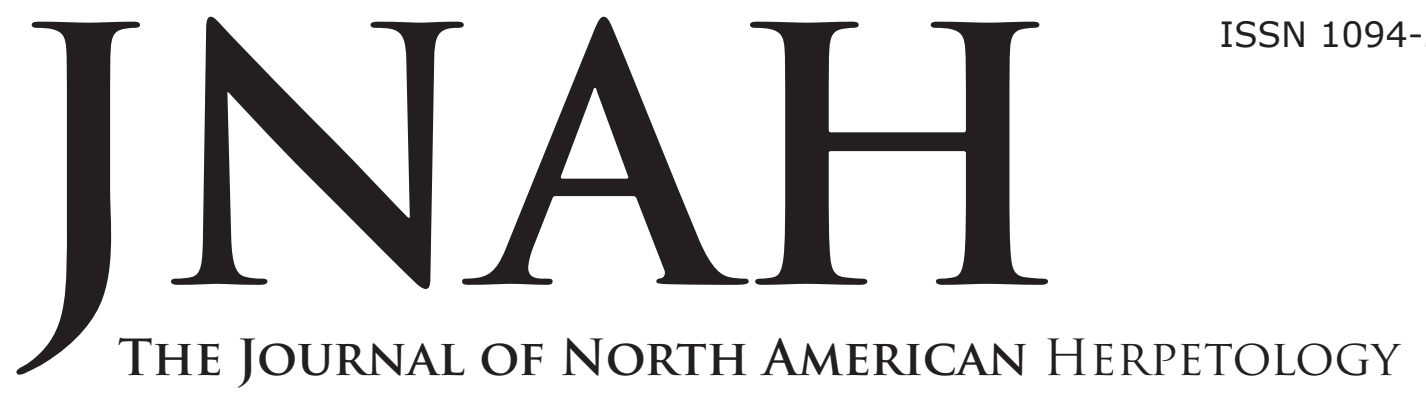

Volume 2016, Number 1

5 July 2016

jnah.cnah.org

\title{
SPATIAL ECOLOGY AND HABITAT USE OF THE WESTERN MASSASAUGA (SISTRURUS TERGEMINUS) IN NEBRASKA
}

\author{
TRACY J. PATTEN ${ }^{1,3}$, DANIEL D. FOGELL ${ }^{2}$, AND JAMES D. FAWCETT ${ }^{1}$ \\ ${ }^{1}$ University of Nebraska at Omaha, Department of Biology, 6001 Dodge \\ Street, Omaha, Nebraska 68182, USA \\ 2 Southeast Community College, 8800 'O' Street, Lincoln, Nebraska \\ 68520, USA, DFogell@southeast.edu \\ ${ }^{3}$ Author for Correspondence: tracycoleman@unomaha.edu
}

\begin{abstract}
We used radiotelemetry during 2004 and 2005 to investigate seasonal movements and habitat use and to improve our understanding of how land management practices were affecting Western Massasauga (Sistrurus tergeminus) populations in Nebraska. We found Western Massasaugas to brumate in crayfish burrows $100 \%$ of the time, and spring emergence occurred during March - April. The longest movements occurred during May when snakes were moving away from brumation sites to summer habitat, after which movements decreased until a second peak in August. We did not find significant differences between male and female activity area, range length, total distance moved, daily movement, or distance from spring and fall brumation sites. However the core activity range of females was significantly less than that of males. During the active season, grassland habitat was used $75.6 \%$ of the time compared to habitats of grassland-shrubs (10.7\%), hydrophilic vegetation $(9.1 \%)$, woodlands $(3.1 \%)$, and shrublands (1.5\%). Identifying variations in a species spatial ecology is important for achieving long-term conservation goals because life history events, resource availability, and land management practices may have an effect on seasonal movements and habitat use. The results of our study demonstrate the need for, and some of the necessary data for, improved land management planning in order to meet conservation needs of the Western Massasauga in Nebraska.
\end{abstract}

KEY WORDS: Conservation, home range, radiotelemetry, rattlesnake, seasonal movements, tallgrass prairie

\section{INTRODUCTION}

The North American tallgrass prairie is one of the most endangered ecosystems on earth, with less than $3 \%$ of its historic range remaining (Mac et al., 1998). Nebraska's tallgrass prairie has declined by $98 \%$ due to agricultural conversion, residential development, and fire suppression (Samson et al., 1998). The Western Massasauga (Sistrurus tergeminus) is a resident of tallgrass prairie in Nebraska and has suffered major population declines as well as severe fragmentation due to habitat loss. As a result, the Nebraska Game and Parks Commission (NGPC) listed the Western Massasauga as a threatened species as well as a Tier I at-risk species (a species that is globally or nationally at risk) (Schneider et al., 2005). The Western Massasauga's total distribution includes southwestern Iowa, northwestern Missouri, eastern Nebraska, Kansas, Oklahoma, and Texas (Conant and Collins, 1998), and its conservation status ranges from critically imperiled (S1) in Nebraska and Iowa to vulnerable (S3S4) in Texas and Kansas, secure (S4) in
Oklahoma, and Not Ranked (SNR) in Missouri (NatureServe, 2010). Currently in Nebraska the Western Massasauga can only be found in remnant tallgrass prairie parcels in four counties (Patten et al., 2009).

Although general life history information about the Eastern Massasauga (Sistrurus catenatus) is well documented, specific data on spatial ecology and habitat use may differ for individual populations of both Eastern and Western Massasaugas facing different types of anthropogenic land use (Szysmanski, 1998). To develop meaningful recommendations for effective habitat management it is important to understand life history events, habitat use, and seasonal movements of populations in Nebraska (Seigel, 1986; Dodd, 1993). Reinert and Kodrich (1982) were the first to study the spatial ecology of the Eastern Massasauga, and subsequent studies have been conducted throughout its range (Weatherhead and Prior, 1992; Mauger and Wilson, 1999; Moore and Gillingham, 2006); however our study was the first to investigate spatial ecology and life history events of 
the Western Massasauga west of the Missouri River. We undertook a radiotelemetry study because it allowed us to repeatedly locate free-ranging animals that would normally be impossible to consistently relocate (Reinert, 1992). Radiotelemetry allowed us to identify variations in spatial ecology resulting from life history events, land management practices, and resource availability (Dodd, 1993; Macartney et al., 1988; Durbian et al., 2008).

Our objective was to identify the spatial requirements, seasonal movements, and habitat use of the Western Massasauga at two state-owned and managed properties where haying and prescribed fire are important management practices for maintaining early-successional habitat for multiple species. We also wanted to determine how current land management practices directly affected the Western Massasauga so that we could provide recommendations for improving habitat management.

\section{MATERIALS AND METHODS}

Study Sites-Our study took place in Pawnee County, Nebraska from March 2004 through October 2005 at two NGPC locations: Pawnee Prairie Wildlife Management Area (WMA) and Burchard Lake WMA, hereafter referred to as Pawnee Prairie or PP and Burchard Lake or BL. Pawnee Prairie is a $\mathbf{3 7 8}$ ha property that is open to fishing and hunting but closed to public vehicular access. The site is a mix of tilled and untilled prairie managed by haying and prescribed fire rotations over the last 30 years (M. Remund, NGPC, pers. comm.). Habitat features on this property include approximately 20 human-made ponds ranging in size from 0.05-0.75 ha, ditches with shrubs and trees, planted tree lines, and poorly drained soils within mesic and xeric prairie. The dominant herbaceous plants include: big bluestem (Andropogon gerardii), switch grass (Panicum virgatum), Indian grass (Sorghastrum nutans), prairie dropseed, (Sporobolus heterolepis) and goldenrod (Solidago spp.). The dominant woody vegetation includes: cottonwood (Populus deltoides), honey locust (Gleditsia triacanthos), Osage orange (Maclura pomifera), roughleaf dogwood (Cornus drummondii), smooth sumac (Rhus glabra), willow (Salex spp.), wild plum (Prunus americana) and red cedar (Juniperus virginiana).

Burchard Lake is a 263 ha property that is accessible to

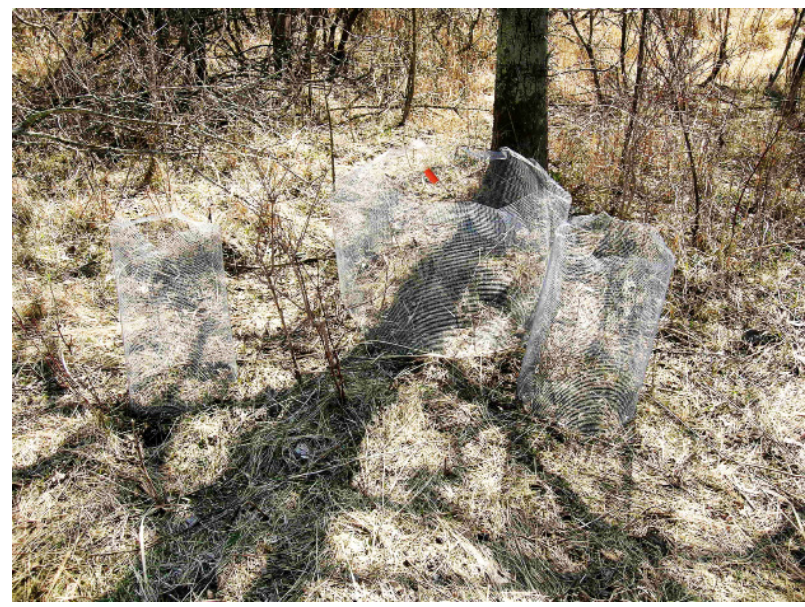

Figure 1. Tubular enclosures made of hardware cloth erected around crayfish burrows where radio-tracked massasaugas were known to have entered brumation so that they could be recaptured during emergence after radiotransmitter batteries had expired. the public by gravel road and is open to fishing, boating, and camping but closed to hunting. This property has a 61 ha human-made lake and a 0.14 ha overflow pond adjacent to the main lake, both surrounded by poorly drained soils, shallow ditches containing trees or shrubs, and rolling mesic to xeric prairie. Burchard Lake is managed by haying and prescribed fire rotations and, more recently, by cattle grazing. Many areas designated as hay plots are dominated by smooth brome (Bromus inermis), vetch (Vicia spp.), sweet clover (Melilotus spp.), and red clover (Trifolium pratense). The lowland areas are primarily composed of reed canary grass (Phalaris arundinacea), cattail (Typha sp.), roughleaf dogwood, and a few stands of prairie cordgrass (Spartina pectinata). The mid-slope and upland prairie consists of big bluestem, switch grass, Indian grass, prairie dropseed, and contains a diverse mix of native and nonnative forbs. Dominant woody vegetation is similar to Pawnee Prairie.

At both study sites the topography consists of rolling hills that we classified as lowland, mid-slope, and upland areas. We defined lowland as those areas with poorly drained soils, ditches, shoreline, and usually having the lowest elevation. Lowlands are the only areas with cattails, reed canary grass, cordgrass, and other hydrophilic vegetation. Mid-slopes are sloped grasslands situated between a lowland and upland. Lowland and mid-slope areas at both WMAs contain burrows constructed by Prairie Crayfish (Procambarus gracilis). Upland areas are flat hilltops usually having the highest elevation of a specific land formation, contain sparse herbaceous vegetation, and are normally absent of woody species and crayfish burrows. Although the lowland areas have some woody vegetation, over $75 \%$ of both WMAs are dominated by grassland.

Radiotelemetry.-Massasaugas were located by performing intense visual searches near brumation areas during spring emergence from March - May of 2004 and 2005. Since massasaugas brumate in crayfish burrows (Maple and Orr, 1968; Reinert, 1978; Johnson, 1995; Mauger and Wilson, 1999) we concentrated search efforts around the main lake and overflow pond at $B L$ and around multiple ponds at PP where crayfish burrows were abundant. We divided PP into north and south sections, with search areas encompassing 20.2 ha in the north and 25.3 ha in the south. Prescribed fire consumed 186.2 ha (north) at PP on 2 April 2004 and 129.5 ha (south) on 27 April 2005. At BL the search area was approximately 10.2 ha. Prescribed fire occurred along 32.4 ha of shoreline at BL on 31 March 2005. Because prescribed fire removed all or most vegetation cover almost all crayfish burrows were exposed resulting in easier detection of massasaugas.

In spring 2004 we implanted 12 snakes with $5.0 \mathrm{~g}$ radio transmitters designed to last 12 months (Model SB-2, Holohil Systems, Ltd.). In spring 2005, we implanted 15 snakes with $9.0 \mathrm{~g}$ radio transmitters designed to last 16 months (Model G3-1V, AVM Instrument Company, Ltd.). Transmitter mass was between 1.4 and $6.6 \%$ of the total body mass of snakes implanted. We used surgical methods described by Reinert and Cundall (1982), and modifications to this procedure recommended by Hardy and Greene (1999, 2001). Three days after surgery, we released the snakes at their point of capture. Snakes were relocated two to three days each week between 0700-2000 h, from May - October and monthly from November - March. For all radiotelemetry locations (hereafter referred to as relocations), a GPS unit (Garmin ${ }^{\circledR}$ eTrex personal navigator) was used to record latitude, 
TABLE 1. Snake ID, sex, study site, snout-vent length (SVL), 100\% minimum convex polygon (MCP), 95\% kernel density (KD) activity range, 50\% KD core activity range, daily movement, range length, total distance moved, number of tracking days, and number of radiotelemetry relocations of Western Massasaugas ( $\mathrm{M}=$ male, $\mathrm{F}=$ female, $\mathrm{G}=$ gravid) during 2004 and 2005 at Burchard Lake (BL) and Pawnee Prairie (PP) Wildlife Management Areas in Nebraska.

\begin{tabular}{|c|c|c|c|c|c|c|c|c|c|c|}
\hline $\begin{array}{l}\text { Snake } \\
\text { ID/Sex }\end{array}$ & $\begin{array}{l}\text { Study } \\
\text { site }\end{array}$ & $\begin{array}{l}\text { SVL } \\
(\mathrm{mm})\end{array}$ & $\begin{array}{l}\text { MCP } \\
\text { (ha) }\end{array}$ & $\begin{array}{l}95 \% \mathrm{KD} \\
\text { (ha) }\end{array}$ & $\begin{array}{l}50 \% \mathrm{KD} \\
\text { (ha) }\end{array}$ & $\begin{array}{c}\text { Range } \\
\text { length }(\mathrm{m})\end{array}$ & $\begin{array}{c}\text { Total } \\
\text { distance }(\mathrm{m})\end{array}$ & $\begin{array}{l}\text { Tracking } \\
\text { days }\end{array}$ & $\begin{array}{l}\text { Tracking } \\
\text { relocations }\end{array}$ & $\begin{array}{c}\text { Tracking } \\
\text { year }\end{array}$ \\
\hline $538 / \mathrm{M}$ & $B L$ & 601 & 10.26 & 13.01 & 1.45 & 729.33 & 2370.68 & 171 & 41 & 2004 \\
\hline 579/M & $B L$ & 510 & 2.10 & 5.03 & 0.77 & 522.50 & 1620.88 & 169 & 42 & 2004 \\
\hline 669/F & $B L$ & 566 & 4.00 & 4.20 & 0.49 & 293.35 & 1810.21 & 171 & 45 & 2004 \\
\hline 787/M & BL & 500 & 8.69 & 13.39 & 1.40 & 524.35 & 3108.30 & 163 & 39 & 2004 \\
\hline 317/M & BL & 529 & 6.06 & 11.21 & 2.01 & 479.00 & 2422.22 & 195 & 50 & 2005 \\
\hline $1768 / M$ & $B L$ & 641 & 18.32 & 23.70 & 4.88 & 784.14 & 3139.87 & 199 & 49 & 2005 \\
\hline $1430 / M$ & $B L$ & 620 & 10.94 & 17.78 & 3.17 & 744.96 & 1605.56 & 178 & 41 & 2005 \\
\hline $1966 / M$ & $B L$ & 673 & 36.68 & 54.95 & 10.90 & 1305.86 & 4804.40 & 193 & 49 & 2005 \\
\hline $560 / M$ & PP & 665 & 9.68 & 3.82 & 0.63 & 617.27 & 2076.09 & 163 & 30 & 2004 \\
\hline $588 / M$ & PP & 585 & 7.01 & 15.16 & 3.79 & 605.49 & 2170.50 & 161 & 35 & 2004 \\
\hline $648 / F$ & PP & 590 & 9.89 & 12.06 & 1.00 & 507.95 & 2162.20 & 161 & 35 & 2004 \\
\hline 707G & PP & 574 & 7.00 & 10.49 & 0.98 & 617.78 & 2020.71 & 171 & 41 & 2004 \\
\hline 728/M & PP & 594 & 14.66 & 21.55 & 3.57 & 722.95 & 2529.53 & 171 & 38 & 2004 \\
\hline $828 / M$ & PP & 625 & 13.20 & 17.40 & 4.58 & 568.77 & 3890.66 & 174 & 39 & 2004 \\
\hline 907/M & PP & 615 & 5.19 & 6.36 & 0.92 & 557.28 & 2791.35 & 174 & 37 & 2004 \\
\hline $1984 / M$ & PP & 702 & 2.94 & 5.56 & 1.10 & 360.17 & 1340.85 & 190 & 44 & 2005 \\
\hline $1076 / \mathrm{M}$ & PP & 630 & 3.52 & 4.94 & 1.45 & 335.13 & 1572.79 & 161 & 41 & 2005 \\
\hline $1187 / F$ & PP & 621 & 2.98 & 1.92 & 0.22 & 325.59 & 1321.14 & 157 & 41 & 2005 \\
\hline 422/M & PP & 575 & 5.73 & 6.14 & 0.82 & 464.11 & 1501.12 & 158 & 36 & 2005 \\
\hline
\end{tabular}

longitude, elevation, date, and time. While we were able to radio-track snakes to the precise burrows they used for brumation, the transmitter batteries expired during winter. Therefore we erected enclosures constructed of hardware cloth formed into a tube and staked them to the ground with tent stakes (Figure 1). This allowed us to guarantee capture of the snakes during spring emergence so that we could either implant a fresh transmitter or retrieve the old transmitter.

Habitat Use-Upon relocation micro-canopy cover, ground cover, and vegetation type were recorded. We recorded tree cover as either present or absent. We collected measurements of ground canopy and micro-canopy cover modified from Daubenmire (1959) with cover categories ranging from $0-25 \%, 26-50 \%, 51-75 \%$, and $76-100 \%$. For our study, micro-canopy was any type of vegetation cover (excluding trees) directly above the snake. Ground cover was any type of vegetation cover over the soil surface and was measured by using a 50 by $50 \mathrm{~cm}$ quadrat centered on the snake. Vegetation was recorded as one of five types: 1) grass-forbs, 2) grass-

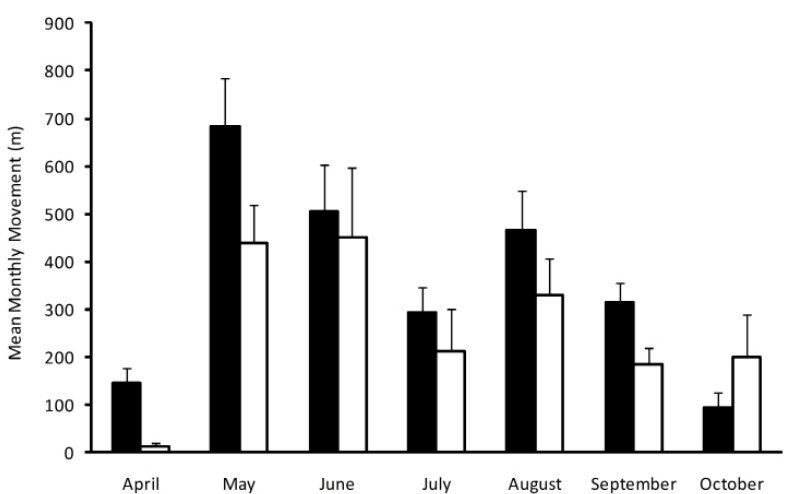

Figure 2. Mean monthly movement $(\mathrm{m})$ by radio-tracked female (white bars) and male (black bars) Western Massasaugas in southeastern Nebraska during 2004 and 2005. Error bars represent \pm 1 SE. forbs-shrubs, 3) shrubs (few or no herbaceous plants), 4) trees-shrubs-herbaceous (wooded area) and 5) hydrophilic vegetation (reed canary grass, cattail, sedge, and prairie cordgrass). The habitat categories were determined by visually identifying all available habitats at both study sites. These five categories include all vegetation types found at both study sites and represent all available habitat excluding open water, agricultural fields, gravel roads, and paved parking lots. In rare cases where snakes were found in locations other than the five selections above, we recorded detailed descriptions. Analytical Methods. - Latitude and longitude for radiotelemetry relocations were overlain onto aerial imagery and analyzed using a Geographic Information System (GIS) program (ArcView ${ }^{\circledR} 3.2$, ESRI Inc., Redlands, CA). In order to obtain accurate home range estimates, researchers need to collect as many data points as possible, quantify the data over a biologically meaningful periods of time (Powell, 2000), and maintain consistency within the sample group. Therefore, only those snakes that were tracked two to three days each week from 1 May - 31 October were included in our activity range and core activity range comparisons. Although emergence occurred during March and April, these months were excluded due to insufficient data. We used the Animal Movements Extension (Hooge, 1998) developed for ArcView 3.2 Spatial Analyst to calculate activity range and core activity range. As suggested by Reinert (1992), we measured total distance moved (sum of all linear distances between locations), range length (linear distance between the two most distant locations), and mean distance moved per day (total distance moved, divided by the total number of days monitored). We also measured the distance between spring emergence site and fall ingress site of radiotracked snakes, referred to as brumation site fidelity.

We calculated the activity range using two methods to facilitate comparison to other massasauga and reptile telemetry studies. We used the $100 \%$ minimum convex polygon (MCP), which measures the area enclosed by 
TABLE 2. Habitat and behavioral variables recorded upon radiotelemetry relocation of Western Massasaugas at Burchard Lake and Pawnee Prairie Wildlife Management Areas in Nebraska during 2004 and 2005.

\begin{tabular}{|c|c|}
\hline Variable & Number of observations (\%) \\
\hline \multicolumn{2}{|c|}{ Location of snake } \\
\hline \multirow{3}{*}{\multicolumn{2}{|c|}{ 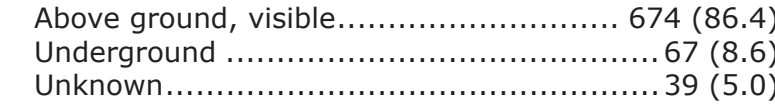 }} \\
\hline & \\
\hline & \\
\hline \multicolumn{2}{|c|}{ Behavior of snake } \\
\hline \multicolumn{2}{|c|}{ Lurking or resting coil ........................ 413 (53.6) } \\
\hline \multicolumn{2}{|c|}{ 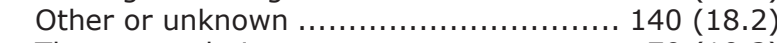 } \\
\hline \multicolumn{2}{|c|}{ Thermoregulating ................................ 79 (10.3) } \\
\hline \multicolumn{2}{|c|}{ 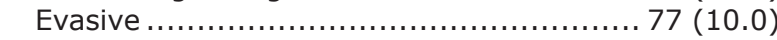 } \\
\hline \multicolumn{2}{|c|}{ 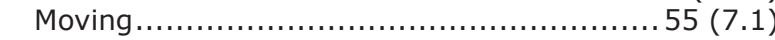 } \\
\hline \multicolumn{2}{|c|}{ Copulating.......................................... } \\
\hline \multicolumn{2}{|c|}{ 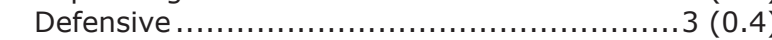 } \\
\hline \multicolumn{2}{|c|}{ Habitat type } \\
\hline \multicolumn{2}{|c|}{ 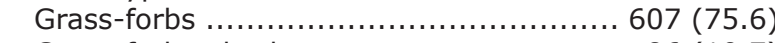 } \\
\hline \multicolumn{2}{|c|}{ Grass-forbs-shrubs $\ldots \ldots \ldots \ldots \ldots \ldots \ldots \ldots \ldots \ldots \ldots \ldots, 86$ (10.7) } \\
\hline \multicolumn{2}{|c|}{ Hydrophillic vegetation $\ldots \ldots \ldots \ldots \ldots \ldots \ldots \ldots . \ldots 73$ (9.1) } \\
\hline \multicolumn{2}{|c|}{ Woodlands..................................... 25 (3.1) } \\
\hline \multicolumn{2}{|c|}{ 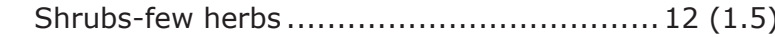 } \\
\hline \multicolumn{2}{|c|}{ Micro-canopy (\%) } \\
\hline \multicolumn{2}{|c|}{$0-25 \ldots \ldots \ldots \ldots \ldots$} \\
\hline \multicolumn{2}{|l|}{$26-50$} \\
\hline \multicolumn{2}{|r|}{$119(16.9$} \\
\hline \multicolumn{2}{|c|}{ 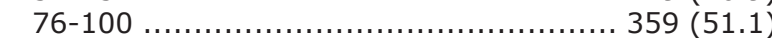 } \\
\hline \multicolumn{2}{|c|}{ Ground canopy (\%) } \\
\hline \multicolumn{2}{|c|}{$0-25 \ldots \ldots \ldots \ldots \ldots$} \\
\hline \multicolumn{2}{|c|}{$26-50 \ldots \ldots \ldots \ldots, \ldots, 1)$} \\
\hline \multicolumn{2}{|c|}{ 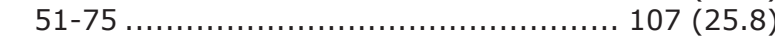 } \\
\hline $76-100$ & $\ldots \ldots \ldots \ldots \ldots \ldots \ldots \ldots 258(62.2)$ \\
\hline
\end{tabular}

the outermost GPS locations. We also used the fixed kernel density (KD) estimator, which determines the activity range of an animal using a probabilistic model (Worton, 1989; Powell, 2000). Using KD, we measured the 95 and $50 \%$ probability estimates that an individual would be in a certain location (Powell, 2000). We used the 95\% $\mathrm{KD}$ as the activity range and the $50 \% \mathrm{KD}$ as the core activity range (Tiebout and Cary, 1987). We compared spatial data using the Wilcoxon Rank Sum Test because data did not conform to normality assumptions required for parametric tests. All statistical tests and descriptive statistics were performed in JMP $®$ 8.0.2 (SAS Institute Inc., 2009) and Excel (Microsoft Office $\AA$ ) with an alpha of 0.05 . Means are reported with \pm 1 Standard Deviation (SD) unless annotated.

\section{RESULTS}

Radiotelemetry. - In spring 2004 we implanted transmitters into four females and eight males. During spring emergence in 2005, five of the 10 remaining snakes that were radio-tracked in 2004 were recaptured. In spring 2005, we implanted transmitters into five females and 10 males of which four had been previously tracked in 2004. The number of relocations ranged from six to 50 (mean $=34 \pm 12.29$ ), and the calendar year tracking period ranged from 23 to 199 days (mean $=142.48$ \pm 51.74 ) for the 27 individuals radio-tracked. For the snakes radio-tracked from May - October, the number of tracking days ranged from 157 to 199 (mean $=172.63$ $\pm 12.95 ; N=19$ ) and the number of relocations using radiotelemetry ranged from 30 to 50 (mean $=40.84 \pm$
5.19; $N=19)$.

Seasonal Movements. - Monthly movements were not analyzed during March and April because emergence dates varied among individuals and crayfish burrows were continually used at this time. However by May of both years all radio-tracked snakes had completely emerged and were not using crayfish burrows. We did not find a significant difference between mean monthly movements among males and females, with the exception of October (outlier excluded: $N=17, S=54, P=$ 0.046; outlier included: $N=18, S=55, P=0.080)$, when females moved greater distances (Figure 2).

The $95 \%$ activity range averaged $13.09 \pm 11.94$ ha and ranged in size from 1.92-54.95 ha (Table 1 ). The MCP activity range averaged $9.41 \pm 7.90$ ha and ranged 2.10-36.68 ha. The $50 \%$ core activity range averaged $2.32 \pm 2.52$ ha and ranged $0.22-10.90$ ha. An outlier was identified, male \#1966, (95 KD = 54.95 ha; $50 \mathrm{KD}$ $=10.90 \mathrm{ha} ; \mathrm{MCP}=36.68 \mathrm{ha})$ resulting in exclusion $(N$ $=18)$ and inclusion $(N=19)$ in statistical comparisons of MCP, activity range, core activity range, daily movement, range length, and total distance moved. No significant difference was detected between male and female activity ranges (MCP outlier included: $N=19, S=30, P$ $=0.342 ; 95 \mathrm{KD}: N=19, S=24, P=0.121$ ) (MCP outlier excluded: $N=18, S=30, P=0.425 ; 95 \mathrm{KD}: N=18, S$ $=24, P=0.152)$, although males in general averaged greater movements (Table 1 ). Female core activity range was significantly less than male core activity range both with the outlier $(N=19, S=18, P=0.032)$ and without $(N=18, S=18, P=0.038)$. Snakes had between one and four core activity ranges ( 1 core, $N=8 ; 2$ core, $N$ $=7 ; 3$ core, $N=3 ; 4$ core, $N=1$ ). Of the four females tracked, three had one core range and one had two core ranges. No significant differences were found between Burchard Lake and Pawnee Prairie activity ranges or core activity ranges with the outlier (MCP: $N=19, S=91, P$ $=0.386 ; 95 \mathrm{KD}: N=19, S=96, P=0.201 ; 50 \mathrm{KD}: N$ $=19, S=91.5, P=0.364$ ) or without the outlier (MCP: $N=18, S=72, P=0.651 ; 95 \mathrm{KD}: N=18, S=77, P=$ $0.365 ; 50 \mathrm{KD}: N=18, S=72.5, P=0.618)$. Statistically significant differences were not detected between study site range length $(N=19, S=94, P=0.265)$, total distance moved $(N=19, S=95, P=0.231)$, or daily movement $(N=19, S=87, P=0.592)$. No statistically significant differences were found in range length $(N=$ $19, S=24, P=0.121)$, total distance moved $(N=19, S$

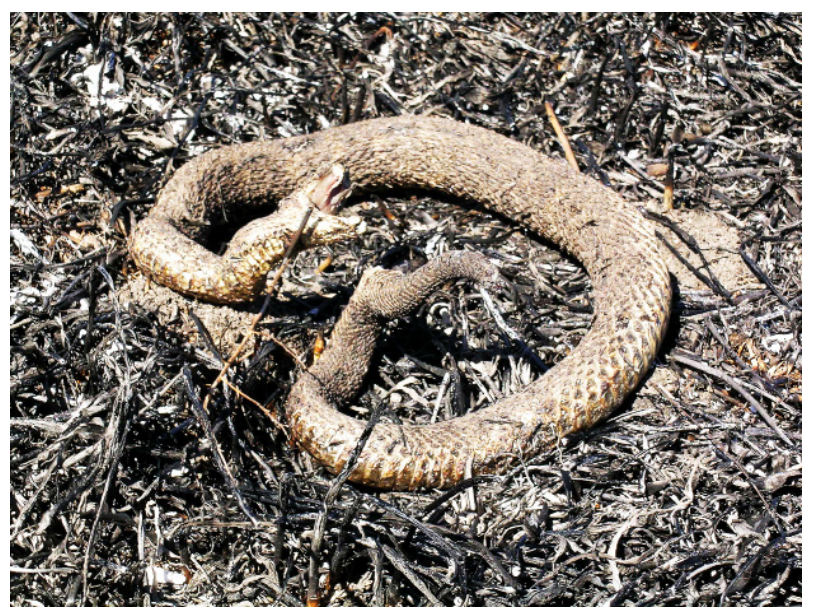

Figure 3. One of four adult Western Massasaugas found burned after a prescribed fire on 1 April 2004. 
$=26, P=0.177)$, or daily movements $(N=19, S=28$, $P=0.250$ ) between males and females.

Brumation and Spring Emergence.-All radio-tracked massasaugas encountered during fall ingress and spring emergence brumated in crayfish burrows. Radio-tracked snakes selected a burrow for brumation between 17 September and 29 October and remained there until March or April for an average of $182.4 \pm 17.18$ days (range $=$ $147-215 ; N=20$ ). In fall massasaugas did not return to the same crayfish burrow that they had emerged from the previous spring; however, most of the snakes chose burrows that were in the same general brumation area. The average straight line distance between spring emergence site and fall ingress site was $180.88 \pm 160.77 \mathrm{~m}$ $(N=19$, range $=15.6-612.52)$ and there was no significant difference in this measurement between study sites $(N=19, S=86, P=0.650)$ or $\operatorname{sex}(N=19, S=49, P$ $=0.395)$. Approximately $48 \%$ of radio-tracked snakes brumated within $90 \mathrm{~m}$ of their previous site. Two snakes brumated at wetlands that were greater than $400 \mathrm{~m}$ from their emergence wetlands.

Western Massasaugas brumated in a variety of habitat types including lowland and mid-slope grassland, reed canary grass, reed canary grass-shrubland, shrubland-grassland edge, woodland-grassland edge, and wetland ditches with herbaceous vegetation and shrubs. Despite the vegetation differences, all sites had a similar characteristic of saturated soils and concentrations of crayfish burrows. During fall ingress and spring emergence multiple snakes were often found using the same crayfish burrow. In one instance, three Western Massasaugas (one adult male, one adult female, one juvenile female) and two Common Gartersnakes (Thamnophis sirtalis) emerged from the same crayfish burrow. On another occasion, an adult male and three juvenile Western Massasaugas (female, male and unknown sex; all having one rattle segment + button) emerged from the same crayfish burrow between 2 and 17 April 2005. On 29 October 2004, an adult male Western Massasauga was hibernating in a crayfish burrow and two juvenile massasaugas (female $=260 \mathrm{~mm} \mathrm{SVL}$, male $=253 \mathrm{~mm}$ SVL) were seen with their heads protruding out of the same burrow.

During emergence Western Massasaugas basked during the warmest part of the day and then retreated into a crayfish burrow until the following day. This behavior was common during spring temperature fluctuations. Once massasaugas emerged, they would move along the shoreline using different burrows for about two

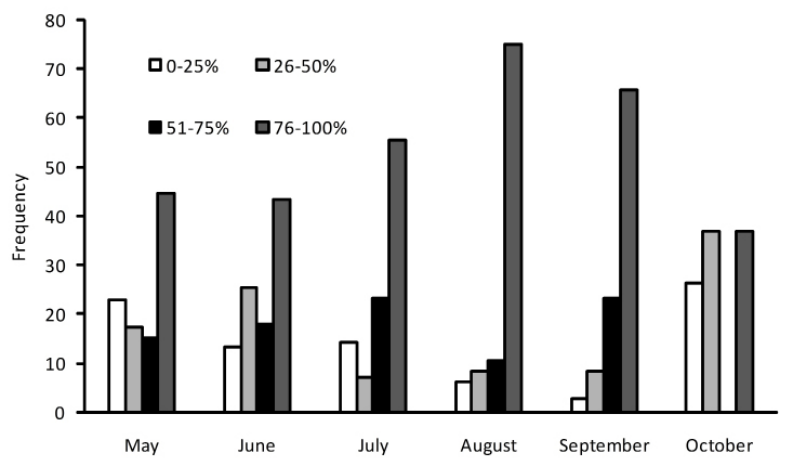

Figure 4. Frequency of micro-canopy cover used by radio-tracked Western Massasaugas in southeastern Nebraska during 2004 and 2005. (May $N=92$; June $N=67$; July $N=56$; August $N=48$; September $N=73$; October $N=19$ ) weeks before moving to active season habitat, at which time crayfish burrows were no longer used. Western Massasaugas that emerged to a complete lack of vegetation after prescribed burns were easily found basking or coiled on bare soil. A visual survey on a post-burn unit during early April 2005 yielded four adult and two juvenile Western Massasaugas along with several birds, mammals, and other herpetofauna that were killed as a result of the prescribed burn (Figure 3 ).

Active Season and Habitat Use.-The active season averaged $180.29 \pm 16.28$ days $(N=19$, range $=150$ 208) from spring emergence until fall ingress. Western Massasaugas did not use crayfish burrows once the active season began; however, terrestrial habitats within brumation areas were occupied throughout the active season. During the active season, grassland habitat was used $75.6 \%$ of the time compared to habitats of grassland-shrubs $(10.7 \%)$, hydrophilic vegetation $(9.1 \%)$, woodlands $(3.1 \%)$, and shrublands $(1.5 \%)$ (Table 2 ). Western Massasaugas were more frequently observed in grassland habitat throughout the study period except during the month of October (Figure 4). Micro-canopy cover averaged $>50 \%$ during all months of the study period except October. Radio-tracked individuals were not observed using upland areas for prolonged periods. Upon telemetry relocation, Western Massasaugas were observed above ground $86.4 \%$ of the time, below ground $8.6 \%$ of the time, and their position could not be identified $5 \%$ of the time (Table 2 ).

Haying occurred during mid-August to early-September on lowland, mid-slope, and upland areas at Burchard Lake (2004 = 34 ha; $2005=27.5$ ha $)$ and Pawnee Prairie $(2004=44.5$ ha; $2005=36.4$ ha $)$. One observed impact from haying was direct mortality $(N=5)$ from machinery in lowland grassland areas (Patten, et al., 2009). Indirect effects included a reduction of available foraging and refuge habitat, and a reduction of connectivity between habitat patches. After an area was hayed, tracked Western Massasaugas were rarely $(N=1)$ relocated in cut hayfields; however, they were found within adjacent fence rows, tree lines, ditches and small patches that had not been hayed. Radio-tracked Western Massasaugas were also observed within these patches or corridors during migration to brumation sites in the fall.

\section{DISCUSSION}

Several studies were previously conducted to quantify seasonal movements and spatial ecology by Eastern Massasaugas (S. catenatus). However given that our study represents one of the first to investigate these characteristics for the Western Massasauga there is a paucity of available literature for comparison; therefore, we compared our results with those published for the eastern species. The active season of 180 days in Nebraska was comparable to 192 days in Pennsylvania (Reinert, 1978), 197.3 days in Missouri (Seigel, 1986), and 158.1 days in New York (Johnson, 1995). The average total distance moved in Nebraska (2329 m) was comparable to three Missouri populations (2325$2753 \mathrm{~m}$ ) (Durbian et al., 2008), a New York population $(2751.3 \mathrm{~m})$ (Johnson, 2000), and an Ontario population $(1823.6 \mathrm{~m}$ ) (Weatherhead and Prior, 1992) but was greater than two Wisconsin populations (548.6-1252.5 $\mathrm{m}$ ) (Durbian et al., 2008). Males in Missouri on average moved greater total distances $(3101 \mathrm{~m})$ and had larger activity areas (95 KD $=25.3 \mathrm{ha} ; 50 \mathrm{KD}=5.0$ ha) (Durbian et al., 2008) than those in Nebraska (total distance $=2463 \mathrm{~m} ; 95 \mathrm{KD}=14.7 \mathrm{ha} ; 50 \mathrm{KD}=2.8 \mathrm{ha}$ ), 
which could be a factor of habitat quality, habitat size, resource availability, or variation in land management practices. In Nebraska, PP and BL mean activity range (9.6 and 17.9 ha, respectively) was comparable to the range of three Missouri populations (6.5-18.8 ha) and two Wisconsin populations ( 7.6 and 25.5 ha) (Durbian et al., 2008). The average activity range for a northeast Indiana population of 4.03 ha and a Michigan population of 1.3 ha was considerably less than those of the former populations, which could be attributed to adequate resources within a small area (Marshall et al., 2006; Moore and Gillingham, 2006). Stickel and Cope (1947) made a general observation about snakes, suggesting that in areas with abundant resources home ranges might be smaller. Additionally, Johnson and Leopold (1998) suggest that non-pregnant female and male massasaugas move further away from brumation sites if those areas have a low relative abundance of small mammals. In conclusion, if spacing of animals is correlated to the relative abundance of resources (Gregory et al., 1987) then we can assume that food resources at the two Nebraska sites were not as abundant as populations exhibiting smaller home ranges. This implies one or both of the following: that Western Massasauga populations at these two Wildlife Management Areas are large, resulting in increased activity ranges to meet resource needs, or that prey resources may have been altered in response to prescribed fire and haying practices. Prescribed fires have been shown to affect small mammal abundance and their use of available habitat (Cook, 1959; Kaufman et al., 1983; Vacanti and Geluso, 1985). This could influence the spatial ecology of massasaugas by necessitating some snakes to increase their activity range or shift their habitat use in order to meet resource requirements.

Our data suggest that females, whether pregnant or non-pregnant, have smaller movement parameters than males, and a similar pattern exists for populations in Missouri and Wisconsin. Similar studies have shown that pregnant females exhibit smaller movement parameters compared to non-pregnant females and males (Brown et al., 1982; Reinert and Zappalorti, 1988; Johnson, 1995). A telemetry study in Ontario concluded that female Eastern Massasaugas do not cover as much area as males, yet are just as active (Weatherhead and Prior, 1992). We found a similar trend as male core activity range was significantly larger than female core activity range while the number of movements was comparable.

Seasonal shift in habitat use has been reported for Eastern Massasauga populations (Reinert and Kodrich, 1982; Seigel, 1986; Weatherhead and Prior, 1992). Johnson (1995) reported similar findings for Eastern Massasaugas in New York, although pregnant females remained near brumation sites during gestation. Both pregnant and non-pregnant females in Nebraska did not remain at brumation sites but moved to mid-slope areas during the active season. Rapid migrations away from brumation sites to summer habitat occurred after a brief period of one to two weeks of thermoregulation. In $\mathrm{Ne}$ braska, Western Massasaugas would often move $>250$ $\mathrm{m}$ in the spring prior to selecting a core activity range, and one snake moved over $1000 \mathrm{~m}$ before selecting a core activity range. During August, massasaugas began a gradual migration in the direction of their fall brumation sites.

During May and June Western Massasaugas were found in $>50 \%$ canopy cover $60 \%$ of the time. The use of $>50 \%$ canopy cover increased to $78 \%$ in July, $85 \%$ in August, and $89 \%$ in September with a sudden decrease in October to only $37 \%$. The seasonal shift could be attributed to a temperature drop in fall when snakes seek basking opportunities or it could merely reflect the amount of available canopy cover as vegetation grows and wilts from spring to fall. It should be noted, however, that the use of grassland habitat decreased while woodland and hydrophilic vegetation use increased during fall. This likely reflects differences in habitat structure and type between brumation sites and active season habitat, even though a significant number of Western Massasaugas brumated in grassland habitat. One caveat worth mentioning is that our study did not differentiate between xeric grasslands and mesic grasslands, where crayfish could construct burrows, because both types had similar vegetation composition.

Non-random movements and non-random use of habitat have been reported for several snake species including Timber Rattlesnakes (Crotalus horridus) (Sealy, 2002), Eastern Massasaugas (Weatherhead and Prior, 1992), Common Gartersnakes (Fitch and Shirer, 1971), and Milk Snakes (Lampropeltis triangulum) (Fitch, 1999). Western Massasaugas that were radio-tracked for two seasons had overlapping activity ranges from year to year and overlap in core range. Otherwise, core ranges between the 19 radio-tracked snakes only overlapped along the edges. In Nebraska, Western Massasaugas revisited previous locations in active season habitat and most returned to the same general brumation area for consecutive years.

Gregory (1984) reported that den fidelity is infrequently $100 \%$, resulting in some interchange between den sites. Distances between dens may affect fidelity. For example with Red-bellied Snakes (Storeria occipitomaculata), Smooth Greensnakes (Opheodrys vernalis) and Common Gartersnakes (Thamnophis sirtalis) Lang (1971) found lower fidelity and greater annual interchange between overwintering sites that were close in proximity. Although brumation structures used by Western Massasaugas may not be fixed locations (i.e. rocky outcrops), they exhibited a level of fidelity to brumation sites by returning to the same general area. Harvey and Weatherhead (2006) reported similar findings for the Eastern Massasauga in Ontario. They also noted that $70 \%$ of the radio-tracked snakes chose brumation sites within $100 \mathrm{~m}$ of the previous site. During our study, the two snakes that did not exhibit hibernation fidelity were successful feeders during the active season and had feeding locations closer to the fall hibernacula compared to the spring emergence location. This indicates that brumation sites may be considered opportunistic rather than fixed for some snakes depending on nearby resources. During fall ingress and spring emergence we found multiple snakes and snake species using the same burrow. Communal denning, both intra- and interspecific, has been documented for many snake species (Gregory, 1984; Fitch, 1999; Fogell, 2000) including Western Massasaugas of this study. Given the importance of suitable cold weather refugia as a limiting resource at middle to northern latitudes, this behavior is not unexpected.

Crayfish populations and grassland habitat are critical for the survival of Western Massasaugas at Pawnee Prairie and Burchard Lake. Proper timing of land management practices should be implemented to alleviate future mortality of Western Massasaugas. Some important life history events where special timing should be considered include: spring emergence during March and 
April; breeding during April and May; foraging from April through September; gestation from May to September; parturition during August and September; and brumation from October to March.

Prescribed burns conducted in Missouri during the summer were shown to have killed Eastern Massasaugas (Durbian, 2006) and spring burns killed Western Massasaugas in Nebraska during this study. To minimize mortality within a population prescribed fire should be limited in size and location and evaluated on a site-by-site basis. Comprehensive land or habitat management planning, especially during spring emergence when snakes are highly concentrated, is critical for long-term protection of any massasauga population. Additionally, since we observed reproductive activity nearly immediately post-emergence, the timing of prescribed fires is also crucial to reproductive success. The current fire regime at both study sites implements prescribed fire in three to five year rotations, during March and April; however, we do not recommend consistently burning brumation sites two weeks before or after the peak Western Massasauga emergence date of 14 April. During our study, Western Massasaugas were found above ground $86 \%$ of the time during the active season; this indicates that an underground retreat from prescribed fire or haying machinery may not be readily available or used. This also necessitates the need for comprehensive planning and site evaluation before conducting intense land management practices. At Pawnee Prairie, prescribed fire consisted of 100-200 ha grassland units rather than small patches, but in the past have been smaller (M. Remund, NGPC, pers. comm.). Prescribed fire is an effective management tool that should continue at both study sites to maintain early-successional grasslands. Nevertheless, incorporating a patchy mosaic, reducing fire unit size, and only burning brumation sites during 1 November - 1 March would limit mortality, as well as, provide habitat and movement corridors for Western Massasaugas.

Haying in massasauga habitat caused direct mortality and habitat loss at the two Nebraska WMAs. Durbian (2006) also reported high mortality rates during summer haying in Missouri. Because successful parturition and survival of offspring are critical for massasauga conservation, haying and baling should be excluded from lowland and mid-slope grasslands and replaced with properly timed prescribed fire. After late-summer and fall haying, snakes were observed moving along vegetated corridors such as fences, tree lines, and ditches rather than through hayed fields where they were observed prior to mowing. The use of mowed fields or edge habitat could cause an increased predation risk for massasaugas due to loss in vegetation cover or use of edge habitat.

Brumation sites should be designated as critical habitat for the Western Massasauga; thus, it is essential to maintain Prairie Crayfish populations by ensuring adequate water levels near existing brumation sites. An additional threat to massasauga habitat at Burchard Lake and Pawnee Prairie is the encroachment of woody vegetation into areas with poorly drained soils where crayfish populations are concentrated. We suggest using periodic management to reduce the presence of woody canopy and to prevent woody plant invasion while taking into consideration Western Massasauga life history events. For example, using heavy machinery to clear trees and shrubs from a brumation area should not occur during the winter when snakes can be trapped in burrows. Because the Western Massasauga relies on burrows constructed by Prairie Crayfish, studying life history characteristics and monitoring crayfish populations in southeastern Nebraska is an important part of Western Massasauga conservation.

\section{ACKNOWLEDGEMENTS}

We thank T. Leonard for his extensive field assistance. Thank you to M. Fritz and M. Remund of NGPC for facilitating use of state property. We thank T. Bragg and J. Peake for earlier edits as well as comments from several anonymous reviewers that greatly improved this manuscript. Funding for this project was provided by USFWS State Wildlife Grant, Nebraska Game and Parks Commission, The Nature Conservancy's J.E. Weaver Competitive Grant, Minnesota Herpetological Society, Center for Great Plains Studies, Nebraska Herpetological Society, and University of Nebraska at Omaha, including; UNO Sponsored Projects, Steele R. Lunt Memorial Fellowship, UNO Biology Graduate Research Funds, and UNO 2005 Summer Graduate Scholarship. Methods used for this study were approved by the Institutional Animal Care and Use Committee (IACUC \# 04-020-50). Snakes were collected under a NGPC permit.

\section{LITERATURE CITED}

Brown, W. S. 1993. Biology, status, and management of the Timber Rattlesnake (Crotalus horridus): A guide for conservation. SSAR Herpetological Circular 22.

Brown, W. S., D. W. Pyle, K. R. Greene, and J. B. Friedlaender. 1982. Movements and temperature relationships of Timber Rattlesnakes (Crotalus horridus) in northeastern New York. Journal of Herpetology 16:151-161.

Conant, R. and J. T. Collins. 1998. A field guide to reptiles and amphibians: eastern and central North America. Houghton Mifflin Co., New York.

Cook, S. F. 1959. The effects of fire on a population of small rodents. Ecology 40:102-108.

Daubenmire, R. 1959. A canopy-coverage method of vegetational analysis. Northwest Science 33:43-64.

Dodd, K. C. 1993. Strategies for snake conservation. In R. A. Seigal and J. T. Collins (eds.), Snakes: Ecology and Behavior, pp. 363-393. Blackburn Press, New Jersey.

Durbian, F. E. 2006. Effects of mowing and summer burning on the Massasauga (Sistrurus catenatus). American Midland Naturalist 155:329-334.

Durbian, F. E., R. S. King, T. Crabhill, H. Lambert-Doherty, and R. A. Seigel. 2008. Massasauga home range patterns in the Midwest. Journal of Wildlife Management 72:754-759.

Fitch, H. S. 1999. A Kansas Snake Community: composition and changes over 50 years. Krieger Publishing Co., Florida.

Fitch, H. S. and H. W. Shirer. 1971. A Radiotelemetric study of spatial relationships in some common snakes. Copeia 1971:118-128.

Fogell, D. D. 2000. Seasonal Activity, Habitat Preferences, and Natural History of the Timber Rattlesnake (Crotalus horridus) in Southeastern Nebraska. Unpubl. MA Thesis, Univ. of Nebraska, Omaha.

Gregory, P. T. 1984. Communal denning in snakes. In R. A. Seigel, L. Hunt, J. Knight, L. Malaret, and N. Zuschlag (eds.), Vertebrate Ecology and Systematics: a Tribute to Henry S. Fitch Museum of Natural History, pp. 57-75. Univ. of Kansas, Lawrence.

Gregory, P. T., J. M. Macartney, and K. W. Larsen. 1987. Spatial patterns and movements. In R. A. Seigel, J. 
T. Collins, and S. S. Novak (eds.), Snakes: Ecology and Evolutionary Biology, pp. 366-395. Macmillan Publishing Company, New York.

Hardy, Sr., D. L., and H. W. Greene. 1999. Surgery on rattlesnakes in the field for implantation of transmitters. Sonoran Herpetologist 12:26-28.

Hardy, Sr., D. L., H. W. Greene, and C. S. Rau. 2001. Anesthesia and surgical techniques for radio-telemetry in rattlesnakes. SEASERG \& SARC Productions. Portal, AZ, USA.

Harvey, S. D. and P. J. Weatherhead. 2006. Hibernation site selection by Eastern Massasauga Rattlesnakes (Sistrurus catenatus catenatus) near their northern range limit. Journal of Herpetology 40:66-73.

Hooge, P. N. 1998. ArcView 3.2 Extension for the analysis of Animal Movement Patterns, version 1.01. Alaska Biological Science Center, U.S. Geological Survey Anchorage, Alaska.

Johnson, G. 1995. Spatial Ecology, Habitat Preference, and Habitat Management of the Eastern Massasauga, Sistrurus c. catenatus in a New York WeakIy-Minerotrophic Peatland. Unpubl. Ph.D Diss., State University of New York, Syracuse.

-----2000. Spatial ecology of the Eastern Massasauga (Sistrurus c. catenatus) in a New York Peatland. Journal of Herpetology 34:186-192.

Johnson, G. and D. J. Leopold. 1998. Habitat management for the Eastern Massasauga in a Central New York peatland. Journal of Wildlife Management 62:84-97.

Kaufman, D. W., G. A. Kaufman, and E. J. Finck. 1983. Effects of fire on rodents in tall grass prairie of the Flint Hills region of eastern Kansas. Prairie Naturalist $15: 49-56$.

Lang, J. W. 1971. Overwintering of Three Species of Snakes in Northwestern Minnesota. Unpubl. Thesis, Univ. of North Dakota, Grand Forks.

Mac, M. J., P. A. Opler, C. E. Puckett Haecker, and P. D. Doran. 1998. Status and trends of the nation's biological resources. 2 vols. U.S. Department of the Interior, U.S. Geological Survey, Reston, Virginia.

Macartney, J. M., P. T. Gregory, and K. W. Larsen. 1988. A tabular survey of data on movements and home ranges of snakes. Journal of Herpetology 22:61-73.

Maple, W. T. and L. P. Orr. 1968. Overwintering adaptations of Sistrurus C. catenatus in northeastern Ohio. Journal of Herpetology 2:179-180.

Marshall, J. C., J. V. Manning, and B. A. Kingsbury. 2006. Movement and macrohabitat selection of the Eastern Massasauga in a fen habitat. Herpetologica 62:141-150.

Mauger, D. and T. P. Wilson. 1999. Population characteristics and seasonal activity of Sistrurus catenatus catenatus in Will County, Illinois: Implications for management and monitoring. In B. Johnson and M. Wright (eds.), Second International Symposium and Workshop on the Conservation of the Eastern Massasauga Rattlesnake, Sistrurus catenatus catenatus: population and habitat management issues in urban, bog, prairie and forested ecosystems, pp. 110-124. Toronto Zoo, Ontario.

Moore, J. A. and J. C. Gillingham. 2006. Spatial ecology and multi-scale habitat selection by a threatened rattlesnake: the Eastern Massasauga (Sistrurus catenatus catenatus). Copeia 2006:742-751.

NatureServe. 2010. NatureServe Explorer: An online encyclopedia of life [web application]. Version 7.1. NatureServe, Arlington, Virginia. Available http:// www.natureserve.org/explorer. (Accessed: September 27, 2010).

Patten, T. J., J. D. Fawcett, and D. D. Fogell. 2009. Natural history of the Western Massasauga (Sistrurus catenatus tergeminus) in Nebraska. Journal of Kansas Herpetology 30:13-20.

Powell, R. A. 2000. Animal home ranges and territories and home range estimators. In L. Boitani and T. K. Fuller (eds.), Research Techniques in Animal Ecology: Controversies and Consequences, pp. 63-110. Columbia University Press, New York.

Reinert, H. K. 1978. The Ecology and Morphological Variation of the Massasauga Rattlesnake, Sistrurus catenatus. Unpubl. Thesis, Clarion State College, Clarion, Pennsylvania.

----1992. Radiotelemetric field studies of pitvipers: data acquisition and analysis. In J. A. Campbell and E. D. Brodie, Jr. (eds.), Biology of the Pitvipers, pp. 185-197. Selva, Tyler, Texas.

Reinert, H. K. and D. Cundall. 1982. An improved surgical implantation method for radio-tracking snakes. Copeia 1982:702-705.

Reinert, H. K. and W. R. Kodrich. 1982. Movements and habitat utilization by the Massasauga, Sistrurus catenatus catenatus. Journal of Herpetology 16:162171.

Reinert, H. K and R. T. Zappalorti. 1988. Timber Rattlesnakes (Crotalus horridus) of the Pine Barrens: Their movement patterns and habitat preference. Copeia 1988:964-978.

Samson, F. B., F. L. Knopf, and W. R. Ostlie. 1998. Grasslands. In M. J. Mac, P. A. Opler, C. E. Puckett Haecker, and P. D. Doran (eds.), Status and Trends of the Nation's Biological Resources, Vol. 2., pp. 437-472. Jamestown, North Dakota.

Schneider, R., M. Humpert, K. Stoner, and G. Steinauer. 2005. The Nebraska Natural Legacy Project: A Comprehensive Wildlife Conservation Strategy. The Nebraska Game and Parks Commission. Lincoln, Nebraska.

Sealy, J. B. 2002. Ecology and behavior of the Timber Rattlesnake (Crotalus horridus) in the Upper Piedmont of North Carolina: identified threats and conservation recommendations. In G. W. Schuett, $M$. Hoggren, M. E. Douglas, and H. W. Greene (eds.), Biology of the Vipers, pp. 561-578. Eagle Mountain Publishing, Utah.

Seigel, R. A. 1986. Ecology and conservation of an endangered rattlesnake, Sistrurus catenatus, in Missouri, USA. Biological Conservation 35:333-346.

Stickel, W. H. and J. B. Cope. 1947. The home ranges and wandering of snakes. Copeia 1947:127-136.

Szymanski, J. 1998. Status assessment for Eastern Massasauga (Sistrurus c. catenatus). U.S Fish and Wildlife Service, Fort Snelling, Minnesota.

Tiebout III, H. M., and J. R. Cary. 1987. Dynamic spatial ecology of the Water Snake, Nerodia sipedon. Copeia 1987:1-18.

Vacanti, P. L., and K. N. Geluso 1985. Recolonization of a burned prairie by Meadow Voles (Microtus pennsylvanicus). Prairie Naturalist 17:15-22.

Weatherhead, P. J. and K. A. Prior. 1992. Preliminary observations of habitat use and movements of the Eastern Massasauga Rattlesnake (Sistrurus c. catenatus). Journal of Herpetology 26:447-452.

Worton, B. J. 1989. Kernel methods for estimating the utility distribution in home-range studies. Ecology 70:164-168. 